\title{
Mechanical Properties of Grains Sorghum Subjected to Compression at Different Moisture Contents
}

\author{
Gabrielly B. Rodrigues ${ }^{1}$, Osvaldo Resende ${ }^{1}$, Daniel E. C. de Oliveira ${ }^{2}$, Lígia C. de M. Silva ${ }^{1}$ \\ $\&$ Weder N. Ferreira Junior ${ }^{1}$ \\ ${ }^{1}$ Instituto Federal de Educação, Ciência e Tecnologia Goiano, Campus Rio Verde, Goiás, Brazil \\ ${ }^{2}$ Instituto Federal de Educação, Ciência e Tecnologia Goiano, Campus Iporá, Goiás, Brazil \\ Correspondence: Gabrielly B. Rodrigues, Instituto Federal de Educação, Ciência e Tecnologia Goiano, Campus \\ Rio Verde, Goiás, Brazil. E-mail: gaby-brodrigues@hotmail.com
}

Received: October 24, 2018

Accepted: January 3, 2019

Online Published: March 15, 2019

doi:10.5539/jas.v11n4p279

URL: https://doi.org/10.5539/jas.v11n4p279

\begin{abstract}
This study aimed to evaluate the influence of drying at different temperatures on the mechanical properties of grains of grain sorghum subjected to compression at the natural rest position. Grains dried at temperatures of 60, 80 and $100{ }^{\circ} \mathrm{C}$ with different moisture contents $(0.515 ; 0.408 ; 0.315 ; 0.234 ; 0.162$ and 0.099 (d.b.)) were subjected to uniaxial compression between two parallel plates, applied at their natural rest position, at a rate of $0.001 \mathrm{~m} \mathrm{~s}^{-1}$. The force required to rupture in grains of grain sorghum increased as their moisture contents decreased, with values of 47.17 to $78.44 \mathrm{~N}, 61.81$ to $69.66 \mathrm{~N}$ and 52.07 to $70.89 \mathrm{~N}$ for the temperatures of 60,80 and $100{ }^{\circ} \mathrm{C}$, respectively. The compression force required to deform grain sorghum decreased with the increment in moisture content, and the proportional deformation modulus increases with moisture content reduction. Within the studied range of moisture content, the values were $87 \times 10^{-7}$ to $354.99 \times 10^{-7} \mathrm{~Pa}, 132.63 \times 10^{-7}$ to $465.98 \times$ $10^{-7} \mathrm{~Pa}$ and $80.18 \times 10^{-7}$ to $429.85 \times 10^{-7} \mathrm{~Pa}$ for the temperatures of 60,80 and $100{ }^{\circ} \mathrm{C}$, respectively.
\end{abstract}

Keywords: compression force, rupture force, Sorghum bicolor

\section{Introduction}

Along the production process, grains are subjected to strong impacts. Steps like harvest, handling, transport and storage can cause damages such as: cracks, fissures and breaks, resulting in a series of problems in the subsequent steps (Amaral, Dobis, \& Carvalho, 2018). Damaged grains cause greater deterioration during storage because they facilitate the action of secondary insects and microorganisms. In addition, dry matter loss is intensified and, consequently, there is loss of nutritional quality, viability and storage potential of the product.

Compression test is a simple experiment where a convex body is compressed between two parallel plates, which is carried out to obtain force-deformation data. This test is performed to obtain parameters which predict the response of the material when subjected to a certain load (Goneli, 2008). Knowing the resistance of grains is indispensable to reduce possible damages and maintain product quality until the processing. Thus, studying mechanical properties becomes necessary to know the behavior and resistance of each product under certain condition.

Several factors can influence the mechanical properties of grains, including drying temperature, moisture content, rigidity and region of the grain where the force is applied (Mohsenin, 1986). Fernandes, Corrêa, Diniz, Leite, and Vasconsellos (2014) observed that the compression force required to deform wheat grain decreases with the increment in moisture content and varied between 139.8 and $21.4 \mathrm{~N}$. Thus, grains with higher moisture contents offer lower resistance to compression.

Ribeiro, Corrêa, Furtado, Goneli, and Resende (2007), evaluating the mechanical properties of soybean grains at different positions, observed that the compression force required to deform the grain by $2 \mathrm{~mm}$ decreased with increasing moisture content. For the position $P_{1}$ (natural rest position), the mean force varied from 302.72 to 72.5 $\mathrm{N}$; for the position $\mathrm{P}_{2}$ (on the hilum), from 127.64 to $41.19 \mathrm{~N}$; and for the position $\mathrm{P}_{3}$ (vertical position), there was variation from 110.86 to $21.72 \mathrm{~N}$, as a function of different moisture contents.

Thus, this study aimed to assess the influence of drying at different temperatures on the mechanical properties of grains of grain sorghum subjected to compression at the natural rest position. 


\section{Material and Methods}

\subsection{Drying of Grains}

The experiment was carried out at the Laboratory of Post-Harvest of Vegetal Products of the Goiano Federal Institute of Education, Science and Technology-Campus of Rio Verde (IF Goiano-Rio Verde Campus), using grains of grain sorghum (Hybrid DKB 540) produced in the municipality of Jataí-GO.

The grains were manually harvested when they had moisture content of about 0.515 (d.b.). After homogenization and preparation of samples, the grains were subjected to drying in a forced-air oven at three temperatures: 60,80 and $100{ }^{\circ} \mathrm{C}$. Relative air humidity was monitored by a psychrometer installed inside the oven.

Moisture content reduction along the drying process was monitored the gravimetric method (mass loss), by knowing the initial moisture content of the product, until a final moisture content of 0.099 (d.b.) was obtained. Mass reduction was monitored using an analytical scale with resolution of $0.01 \mathrm{~g}$. During the drying process, the moisture contents were obtained: $0.515 ; 0.408 ; 0.315 ; 0.234 ; 0.162$ and 0.099 (d.b.), the samples were homogenized and mechanical properties were determined, in three replicates.

The moisture content of the product was determined by the oven method, at $105 \pm 3{ }^{\circ} \mathrm{C}$, for $24 \mathrm{~h}$, in three replicates (Brasil, 2009). For each moisture content obtained, the samples were homogenized and subjected compression test.

\subsection{Mechanical Properties of Grains}

The experimental tests of compression of the grains, tested individually, were carried out with a universal testing machine "TA Hdi Texture Analyser", using a $250 \mathrm{~N}$ load cell.

The grains were subjected to uniaxial compression, between two parallel plates, at their natural rest position (Figure 1), and the force was applied at rate of $0.001 \mathrm{~m} \mathrm{~s}^{-1}$, on 15 grains of grain sorghum (Oliveira, Resende, \& Devilla, 2017).

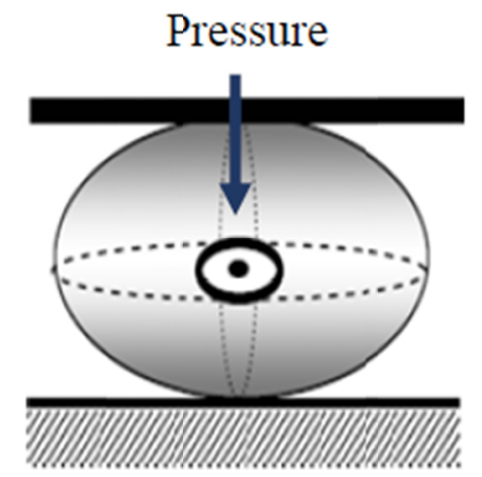

Figure 1. Orientation of grains of grain sorghum during the compression test at their natural rest position

After obtaining the force-deformation curves of the grains, the force and deformation at rupture were determined, which provide the bioyield point. This point is defined as the position at the curve where there is an increase in product deformation associated with a reduction in compression force (ASAE, 1974), indicating the beginning of rupture and the structural disorganization of the products.

The proportional deformation modulus of grains of grain sorghum (Ep) was determined according to Equation 1, obtained for the deformations of $0.1 \times 10^{-3}, 0.2 \times 10^{-3}, 0.3 \times 10^{-3}, 0.4 \times 10^{-3}, 0.5 \times 10^{-3}, 0.6 \times 10^{-3}, 0.7 \times 10^{-3}, 0.8$ $\times 10^{-3}, 0.9 \times 10^{-3}, 1.0 \times 10^{-3} \mathrm{~m}$, adapted from the deformations used by Batista, Couto, Cecon and Peixoto (2003).

$$
\mathrm{Ep}=\frac{\mathrm{E}}{1-\mu^{2}}=\frac{0.531 \times \mathrm{F}}{\mathrm{D}^{\frac{3}{2}}} \times\left[2 \times\left(\frac{1}{\mathrm{r}}+\frac{1}{\mathrm{R}}\right)^{\frac{1}{3}}\right]^{\frac{3}{2}}
$$

where, Ep: proportional deformation modulus, Pa; E: elasticity modulus, Pa; F: compression force, N; $\mu$ : Poisson's ratio, ranging from 0.2 to 0.5 for agricultural products; D: total deformation (elastic + plastic), $\mathrm{m}$; $\mathrm{r}$ and $\mathrm{R}$ : radiuses of curvature of the body at the contact points, $\mathrm{m}$. 
The slope of the force-deformation curve for any point is considered as the tangent $(\mathrm{T})$, obtained by Equation 2 .

$$
\mathrm{T}=\mathrm{d}+2 \mathrm{e} \cdot \mathrm{x}+3 \mathrm{f} \cdot \mathrm{x}^{2}
$$

The maximum tangent is obtained at the inflection point of the curve, where $\mathrm{x}=-\mathrm{e} / 3 \mathrm{f}$, considered as an indicator of product hardness (Resende, 2007).

The secant (S), slope of the line passing through the origin and through any point of the curve, is expressed by the following equation:

$$
\mathrm{S}=\mathrm{d}+\mathrm{e} \cdot \mathrm{x}+\mathrm{f} \cdot \mathrm{x}^{2}
$$

The maximum secant corresponds to the point where deformation is $x=-e / 2 f$, describing the elasticity at different levels of deformation (Resende, 2007).

The radiuses of curvature ( $\mathrm{r}$ and $\mathrm{R}$ ) of the grains at the contact point were obtained by adjusting the circumference to the curvature of the body, based on the coordinate planes relevant to the compression position according to Couto, Batista, Peixoto and Devilla (2002), as illustrated in Figure 3.

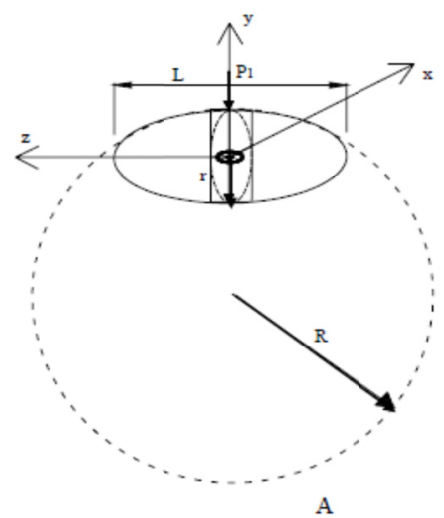

Figure 2. Radius of curvature of grains of grain sorghum (Sorghum bicolor L. Moench) at the region of contact between product and compression plate, where $\mathrm{L}$ is width and $\mathrm{P} 1$ is the force applied at natural rest position

The data of rupture force, deformation at rupture, maximum compression force and proportional deformation modulus of grain sorghum were represented as a function of moisture content.

The experiment was set up in a triple factorial scheme, $3 \times 6 \times 10$ (3 drying temperatures, 6 moisture contents, and 10 deformations), in a completely randomized design, with 15 repetitions. The data were analyzed by regression.

\section{Results and Discussion}

Table 1 shows the values of the physical dimensions of sorghum grains, characterized by length, width and thickness, at all evaluated temperatures and water contents. Note that there is a great variability in the shape and size of the grains, showing no behavior pattern with the reduction of water content. 
Table 1. Values of the physical dimensions of sorghum grains, length (L), width (W) and thickness (T) at temperatures of 60,80 and $100{ }^{\circ} \mathrm{C}$

\begin{tabular}{|c|c|c|c|c|c|c|c|c|c|}
\hline \multirow{3}{*}{$\begin{array}{l}\text { Moisture content } \\
\text { (decimal, d.b.) }\end{array}$} & \multicolumn{9}{|c|}{ Temperature } \\
\hline & \multicolumn{3}{|c|}{$60^{\circ} \mathrm{C}$} & \multicolumn{3}{|c|}{$80^{\circ} \mathrm{C}$} & \multicolumn{3}{|c|}{$100{ }^{\circ} \mathrm{C}$} \\
\hline & Length & Width & Thickness & Length & Width & Thickness & Length & Width & Thickness \\
\hline 0.515 & 4.920 & 4.526 & 2.948 & 4.832 & 3.975 & 2.840 & 4.947 & 4.413 & 2.744 \\
\hline 0.408 & 4.965 & 4.572 & 2.943 & 4.791 & 4.176 & 2.795 & 4.847 & 4.511 & 2.846 \\
\hline 0.315 & 4.683 & 4.349 & 2.695 & 4.793 & 4.058 & 2.712 & 4.836 & 4.412 & 2.663 \\
\hline 0.234 & 4.832 & 4.457 & 2.818 & 4.831 & 4.107 & 2.780 & 4.821 & 4.228 & 2.682 \\
\hline 0.162 & 4.891 & 4.108 & 2.727 & 4.740 & 4.145 & 2.707 & 4.627 & 4.273 & 2.532 \\
\hline 0.099 & 4.745 & 3.918 & 2.676 & 4.559 & 3.938 & 2.651 & 4.406 & 3.935 & 2.373 \\
\hline
\end{tabular}

Table 2 shows the mean values of radius of curvature of the grains of grain sorghum for different drying temperatures and moisture contents used in the determination of the proportional deformation modulus. Radius values oscillated among the different moisture contents, not showing a clear behavior for the different drying temperatures.

Table 2. Mean values of radiuses of curvature of the grains of grain sorghum $(\mathrm{m})$ for each moisture content $(\%$ d.b.)

\begin{tabular}{|c|c|c|c|c|c|c|}
\hline \multirow{3}{*}{$\begin{array}{l}\text { Moisture content } \\
\text { (decimal, d.b.) }\end{array}$} & \multicolumn{6}{|c|}{ Temperature } \\
\hline & \multicolumn{2}{|c|}{$60{ }^{\circ} \mathrm{C}$} & \multicolumn{2}{|c|}{$80^{\circ} \mathrm{C}$} & \multicolumn{2}{|c|}{$100^{\circ} \mathrm{C}$} \\
\hline & $\mathrm{R}$ & $\mathrm{r}$ & $\mathrm{R}$ & $\mathrm{R}$ & $\mathrm{R}$ & $\mathrm{r}$ \\
\hline 0.515 & 0.00325 & 0.00384 & 0.00384 & 0.00258 & 0.00402 & 0.00333 \\
\hline 0.408 & 0.00329 & 0.00382 & 0.00380 & 0.0029 & 0.00377 & 0.00331 \\
\hline 0.315 & 0.00335 & 0.00371 & 0.00381 & 0.00281 & 0.00398 & 0.00344 \\
\hline 0.234 & 0.00314 & 0.00381 & 0.00388 & 0.0028 & 0.00401 & 0.00319 \\
\hline 0.162 & 0.00303 & 0.00391 & 0.00397 & 0.00293 & 0.00380 & 0.00336 \\
\hline 0.099 & 0.00269 & 0.00379 & 0.00376 & 0.00272 & 0.00373 & 0.00310 \\
\hline
\end{tabular}

Note. $\mathrm{r}$ and $\mathrm{R}=$ radiuses of curvature of the body at the contact points, $\mathrm{m}$.

Radiuses of curvature $(\mathrm{R}, \mathrm{r})$ are obtained based on physical dimensions. Thus, grain size has great influence on these estimates. Such variation observed in the data of radiuses at different moisture contents may have been caused by heterogeneity in the shape and size of sorghum grains. Oliveira et al. (2017), evaluating the mechanical properties of baru fruits, and Fernandes et al. (2014), working with wheat grains, obtained similar results.

Table 3 presents the values of total deformation (D), elasticity modulus (E), maximum compression force (F), tangent and secant at the different moisture contents and drying temperatures evaluated. 
Table 3. Values of deformation (D), elasticity modulus (E), maximum compression force (F), tangent and secant at temperatures of 60,80 and $100^{\circ} \mathrm{C}$

\begin{tabular}{|c|c|c|c|c|c|}
\hline Moisture content (decimal, d.b.) & $\mathrm{D}$ & $\mathrm{E}$ & $\mathrm{F}$ & Tangent $\left(\mathrm{N} \mathrm{mm}^{-1}\right)$ & Secant $\left(\mathrm{N} \mathrm{mm}^{-1}\right)$ \\
\hline \multicolumn{6}{|l|}{$60^{\circ} \mathrm{C}$} \\
\hline 0.515 & 29.20 & -128.40 & 360.66 & 127.12 & 70.54 \\
\hline 0.408 & 37.52 & -159.10 & 417.53 & 156.20 & 86.76 \\
\hline 0.315 & 41.46 & -149.66 & 483.31 & 160.22 & 93.12 \\
\hline 0.234 & 40.47 & -130.49 & 363.27 & 139.71 & 82.28 \\
\hline 0.162 & 76.64 & -431.93 & 1316.81 & 414.11 & 221.76 \\
\hline 0.099 & 121.70 & -769.23 & 2295.30 & 719.07 & 377.42 \\
\hline \multicolumn{6}{|l|}{$80^{\circ} \mathrm{C}$} \\
\hline 0.515 & 42.46 & -206.04 & 583.83 & 200.02 & 109.12 \\
\hline 0.408 & 40.11 & -161.68 & 441.48 & 162.31 & 91.34 \\
\hline 0.315 & 52.31 & -299.90 & 846.21 & 281.35 & 149.11 \\
\hline 0.234 & 71.83 & -431.29 & 1245.82 & 403.58 & 212.82 \\
\hline 0.162 & 127.48 & -833.90 & 2502.78 & 776.15 & 405.51 \\
\hline 0.099 & 147.30 & -967.62 & 3029.83 & 908.90 & 476.59 \\
\hline \multicolumn{6}{|l|}{$100^{\circ} \mathrm{C}$} \\
\hline 0.515 & 26.99 & -120.60 & 377.24 & 121.88 & 68.01 \\
\hline 0.408 & 25.77 & -101.33 & 314.79 & 105.36 & 60.13 \\
\hline 0.315 & 34.51 & -144.74 & 394.12 & 143.81 & 80.30 \\
\hline 0.234 & 49.35 & -254.68 & 732.09 & 244.95 & 132.38 \\
\hline 0.162 & 124.28 & -787.47 & 2570.68 & 750.92 & 397.39 \\
\hline 0.090 & 142.27 & -920.98 & 3133.83 & 882.80 & 467.42 \\
\hline
\end{tabular}

It can be noted that, at all drying temperatures, the values of the respective coefficients analyzed tended to increase with moisture content reduction. In addition, the lowest values in general were found at temperature of $60{ }^{\circ} \mathrm{C}$, indicating that high drying temperatures may cause alterations in the characteristics of hardness and elasticity of the grains.

At temperatures of 80 and $100{ }^{\circ} \mathrm{C}$, the values of maximum secant showed the same trend as those of maximum tangent, but with lower magnitude. According to Goneli (2008), the maximum secant, besides indicating the maximum value of the force-deformation curve where the tangent passes through the origin, also indicates the point at which the curve begins to drop, which represents the moment in which the behavior of the product changes from elastic to plastic. For Henry, Su and Zhang (2000), the maximum value of the secant represents the ability of the material to resist to deformation before the maximum elastic value is found.

For all drying temperatures evaluated, there was an increase in rupture force with moisture content reduction, as presented in Figure 4. These values ranged from 78.45 to $47.18 \mathrm{~N}$ for temperature of $60{ }^{\circ} \mathrm{C}, 66.66$ to $61.82 \mathrm{~N}$ for $80{ }^{\circ} \mathrm{C}$ and 70.90 to $52.08 \mathrm{~N}$ for $100^{\circ} \mathrm{C}$.

Resende, Corrêa, Ribeiro, and Neto Figueiredo (2013), evaluating rough and dehulled rice grains, observed similar behavior, where the reduction in moisture content from 0.30 to 0.12 (d.b.) resulted in increment in rupture force from 48 to $79.5 \mathrm{~N}$ for rough rice and 37.2 to $70.6 \mathrm{~N}$ for dehulled rice grains. Such variation in the force required to cause rupture in the physical structure of the grains is directly associated with the moisture content of the biological material, as well as with its physical resistance. 


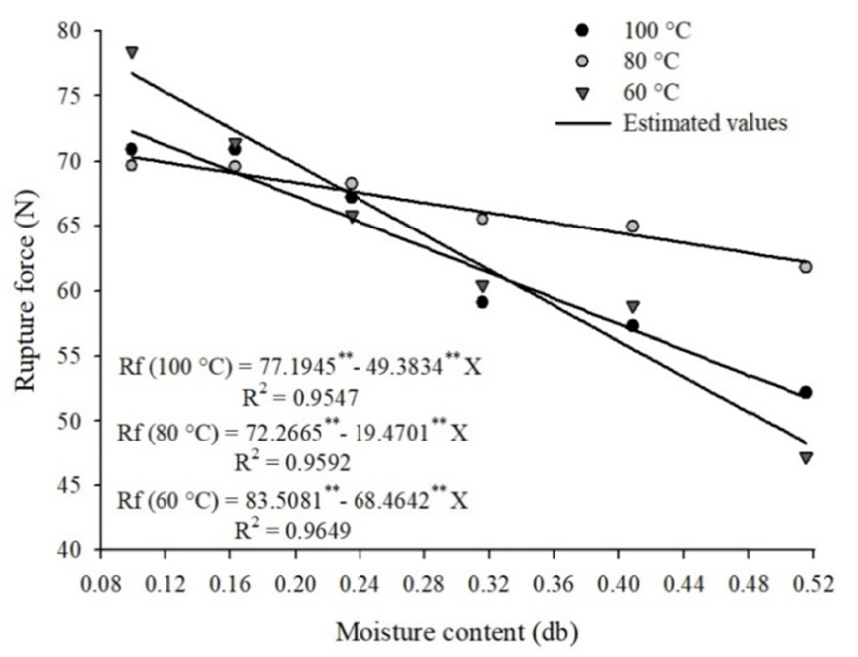

Figure 3. Experimental and estimated values of rupture force as a function of moisture content in grains of grain sorghum

These results indicate that, the higher the moisture content of sorghum grains, the lower their resistance to compression and rupture, and such trend increases linearly due to the reduction in moisture content. According to Gupta and Das (2000), such behavior is due to alterations in the arrangement of the cell matrix of the product, which occurs as moisture content decreases due to the drying process, causing greater rigidity in the integument of the grains, hence providing greater physical protection. Thus, grains which have lower moisture contents in their constitution become more rigid, requiring higher forces to cause any type of mechanical damage.

The mean values of maximum compression force at the three drying temperatures and different moisture contents for several deformations are shown in Figure 4. The results corroborate those of Figure 3, i.e., the lower the moisture content in the grains, the higher the compression force required to cause deformation in the integument of sorghum grains at natural rest position, thus the higher their physical resistance to these damages. In addition, it can also be observed that deformation force values are proportional to the increase in deformation, i.e., the higher the pressure exerted on the grains, the greater the deformation caused in the product. These results agree with those of Fernandes et al. (2014), Henry et al. (2000) and Resende et al. (2007), who evaluated wheat, soybean and bean grains, respectively.

(A)

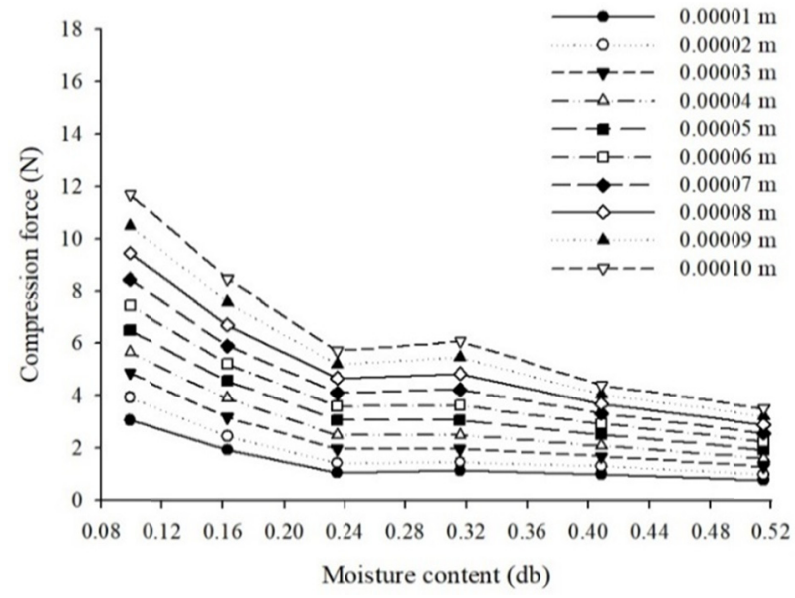

(B)

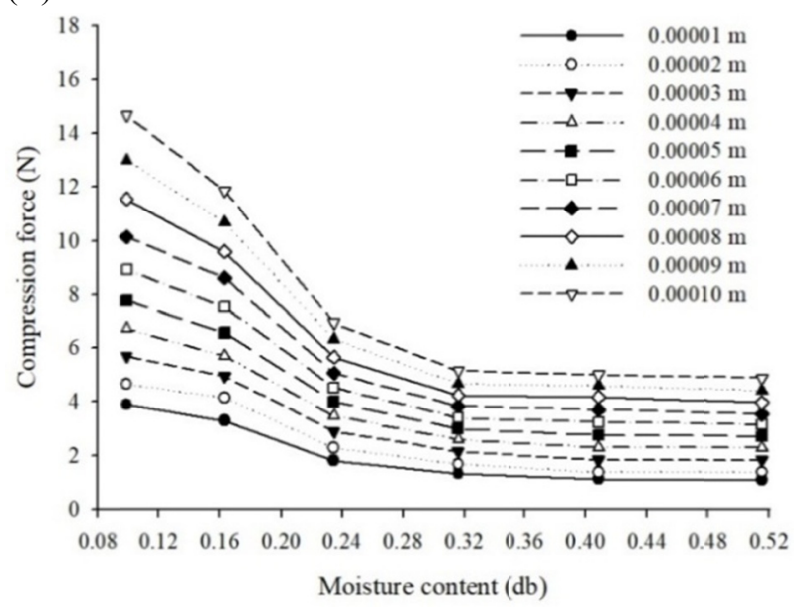




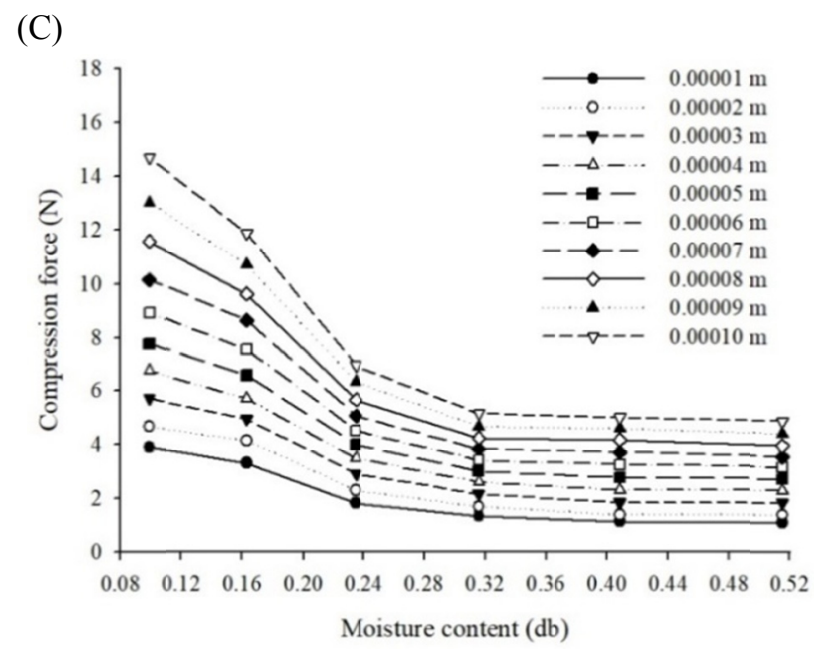

Figure 4. Mean maximum values of compression force for the drying temperatures of 60 (A), 80 (B) and 100 (C) ${ }^{\circ} \mathrm{C}$ as a function of moisture content

Table 4 presents the regression equations fitted to the experimental values of the proportional deformation modulus of grain sorghum, as a function of moisture content and deformation for each temperature evaluated along with the coefficients of determination $\left(\mathrm{R}^{2}\right)$, which were higher than $75 \%$, thus being satisfactory to represent the data.

Table 4. Equations fitted to the experimental values of the proportional deformation modulus of grains of grain sorghum (Ep) as a function of moisture content (MC), for the drying temperatures

\begin{tabular}{lll}
\hline Temperature $\left({ }^{\circ} \mathrm{C}\right)$ & Model & $\mathrm{R}^{2}$ \\
\hline 60 & $\mathrm{Ep}=328.710-740.374 \cdot \mathrm{MC} \cdot \mathrm{D}+626.523 \cdot \mathrm{MC}^{2}+29958447225.534 \cdot \mathrm{D}^{2}+3698308.165 \cdot \mathrm{MC} \cdot \mathrm{D}$ & $0.7769^{* *}$ \\
80 & $\mathrm{Ep}=477.537-1060.670 \cdot \mathrm{MC}+8264745.671 \cdot \mathrm{D}+879.416 \cdot \mathrm{MC}^{2}+45399715991.174 \cdot \mathrm{D}^{2}+5556825.206 \cdot \mathrm{MC} \cdot \mathrm{D}$ & $0.8003^{* *}$ \\
100 & $\mathrm{Ep}=441.182-1171.008 \cdot \mathrm{MC}+6820791.310 \cdot \mathrm{D}+1014.723 \cdot \mathrm{MC}^{2}+35654616708.231 \cdot \mathrm{D}^{2}+5578583.307 \cdot \mathrm{MC} \cdot \mathrm{D}$ & $0.7789^{* *}$ \\
\hline
\end{tabular}

Note. $\mathrm{D}=$ Total deformatiom, $\mathrm{m}$; ${ }^{*}$ Significant at 0.01 probability level by $\mathrm{F}$ test.

Figure 5 presents the values of the proportional deformation modulus of sorghum grains obtained from compression force data. High values of deformation modulus denote that a higher force must be applied to the product to obtain certain deformation (BATISTA et al., 2003).

(A)

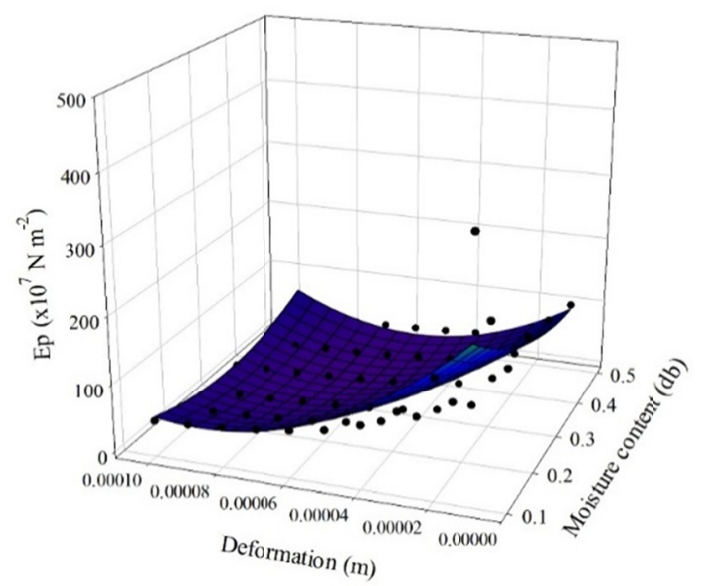

(B)

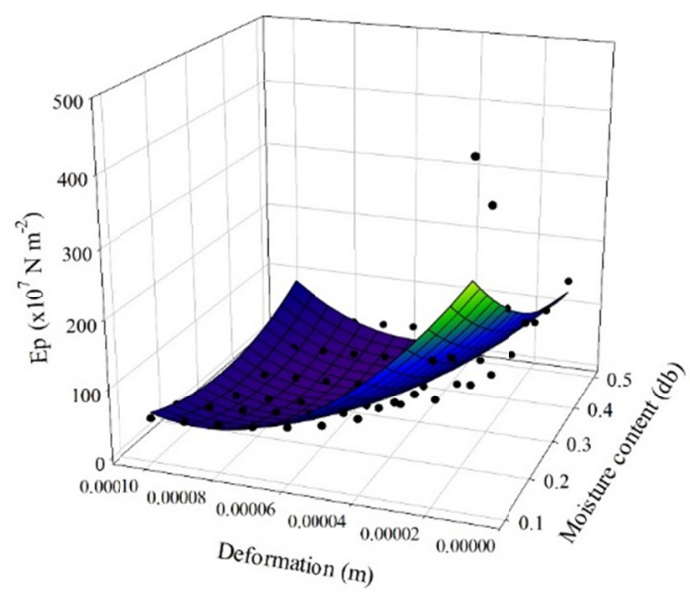


(C)

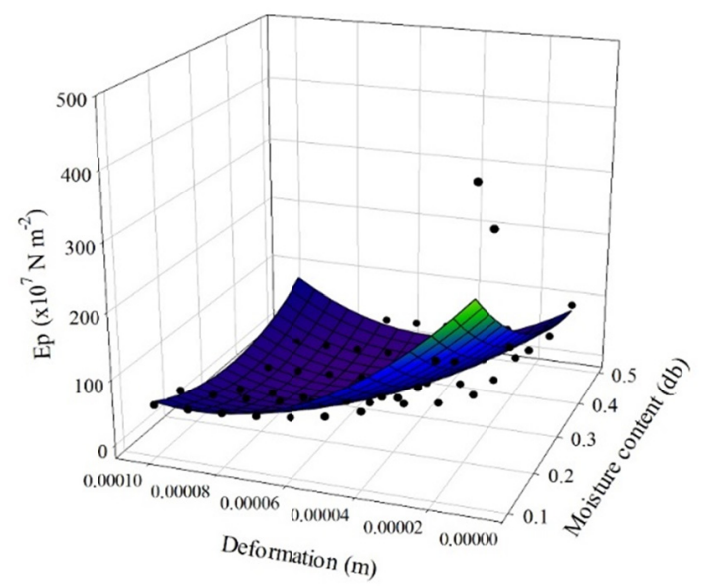

Figure 5. Mean values of proportional deformation modulus of grains of grain sorghum $\left(\mathrm{N} \mathrm{m}^{-2}\right)$, as a function of moisture content (decimal, d.b.) and deformation for the drying temperatures of 60,80 and $100{ }^{\circ} \mathrm{C}$

It can be noted that, at all temperatures evaluated, the proportional deformation modulus tends to increase as moisture content decreases. However, decreasing linear forces are required according to the deformation caused in the grains of grain sorghum at natural rest position. Proportional deformation modulus values ranged from $12.43 \times 10^{-7}$ to $42.72 \times 10^{-7} \mathrm{~Pa}, 18.65 \times 10^{-7}$ to $55.56 \times 10^{-7} \mathrm{~Pa}$ and $12.46 \times 10^{-7}$ to $59.96 \times 10^{-7} \mathrm{~Pa}$ for the temperatures of 60,80 and $100{ }^{\circ} \mathrm{C}$, respectively. These results corroborate those observed by Fernandes et al. (2014), who found proportional deformation modulus ranging from $8.9 \times 10^{7}$ to $51.2 \times 10^{7} \mathrm{~Pa}$ with moisture content varying from 0.26 to 0.14 (d.b.).

Resende et al. (2007), working with bean grains at three different positions of compression, obtained proportional deformation modulus of 4.1 to $71.3 \times 10^{7} \mathrm{~Pa}$ for the position $\mathrm{P} 1,2.6$ to $56.4 \times 10^{7} \mathrm{~Pa}$ for the position P2 and 1.7 to $48.7 \times 10^{7} \mathrm{~Pa}$ for the position P3. Oliveira et al. (2017) evaluated baru fruits and observed that, for the moisture contents studied, the values of proportional deformation modulus varied from $0.96 \times 10^{6}$ to $31.14 \times 10^{6}$, from $0.84 \times 10^{6}$ to $34.46 \times 10^{6}$ and from $0.5 \times 10^{6}$ to $12.15 \times 10^{6} \mathrm{~Pa}$ for 60,80 and $100^{\circ} \mathrm{C}$, respectively. For Batista et al. (2003), high values of the proportional deformation modulus indicate that higher force needs to be applied to the product to cause certain deformation.

\section{Conclusions}

Reduction in moisture content causes a linear increase in secant and tangent values.

The compression force required to cause rupture in the integument of grains of grain sorghum decreases with increasing moisture content, for the different levels of deformation, showing values from 47.17 to $78.44 \mathrm{~N}, 61.81$ to $69.66 \mathrm{~N}$ and 52.07 to 70.89 for temperatures of 60,80 and $100{ }^{\circ} \mathrm{C}$, respectively.

Proportional deformation modulus increases with moisture content reduction and product deformation, with values from $87 \times 10^{-7}$ to $354.99 \times 10^{-7} \mathrm{~Pa}, 132.63 \times 10^{-7}$ to $465.98 \times 10^{-7} \mathrm{~Pa}$ and $80.18 \times 10^{-7}$ to $429.85 \times 10^{-7} \mathrm{~Pa}$ for temperatures of 60,80 and $100^{\circ} \mathrm{C}$, respectively.

Based on the values obtained for deformation modulus and compression force, it can be concluded that grains with lower moisture content may have better performance when subjected to pressure at harvest and postharvest steps.

\section{Acknowledgements}

The authors extend thanks to IF Goiano, CAPES, FAPEG, FINEP and CNPq for their financial support, which was indispensable to the execution of this study.

\section{References}

Amaral, D. R., Dobis, F. S., \& Carvalho, T. C. (2018). Avaliação da qualidade física e físiológica de sementes de soja durante o beneficiamento. Pesquisa Aplicada \& Agrotecnologia, 11(2), 43-52.

ASAE (American Society of Agricultural Engineers). (1974). Agricultural Engineers Yearbook of Standards St. Joseph, MI. 
Batista, C. S., Couto, S. M., Cecon, P. R., \& Peixoto, A. B. (2003). Efeito da temperatura do ar de secagem, do teor de umidade e do estádio de maturação no módulo de deformidade de frutos de café (Coffea arabica L.). Revista Brasileira de Armazenamento, Especial Café(6), 42-53.

Brasil. (2009). Regras para análise de sementes. MAPA/ACS, Ministério da Agricultura e Reforma Agrária, Secretaria Nacional de Defesa Agropecuária Brasília.

Couto, S. A., Batista, C. S., Peixoto, A. B., \& Devilla, I. A. (2002). Comportamento mecânico de frutos de café: Módulo de deformidade. Revista Brasileira de Engenharia Agrícola e Ambiental, 6(2), $285-294$. https://doi.org/10.1590/S1415-43662002000200018

Fernandes, L. S., Corrêa, P. C., Diniz, M. D. M. S., Leite, D. M., \& Vasconcellos, D. S. L. (2014). Influência do teor de água nas propriedades mecânicas dos grãos de trigo submetidos à compressão. Bioscience Journal, 30(1), 219-223.

Goneli, A. L. D. (2008). Variação das propriedades físico-mecânicas e da qualidade da mamona (Ricinus communis L.) durante a secagem e o armazenamento (Tese de Doutorado, Universidade Federal de Viçosa).

Gupta, R. K., \& Das, S. K. (2000). Fracture resistance of sunflower seed and kernel to compressive loading. Journal of Food Engineering, 46(2), 1-8. https://doi.org/10.1016/S0260-8774(00)00061-3

Henry, Z. A., Su, B., \& Zhang, H. (2000). Resistance of soy beans to compression. Journal of Agricultural Engineering Research, 76(2), 175-181. https://doi.org/10.1006/jaer.2000.0546

Mohsenin, N. N. (1986). Physical properties of plant and animal materials. New York: Gordon and Breach Publishers.

Oliveira, D. E. C., Resende, O., \& Devilla, I. A. (2017). Mechanical properties of baru fruit (Dipteryx alata Vogel). Semina: Ciências Agrárias, 38(1), 185-196. https://doi.org/10.5433/1679-0359.2017v38n1p185

Resende, O. (2006). Variação das propriedades físicas e mecânicas e da qualidade do feijão (Phaseolus vulgaris L.) durante a secagem e o armazenamento (Tese de Doutorado, Universidade Federal de Viçosa).

Resende, O., Corrêa, P. C., Oliveira, G. H. H., Goneli, A. L. D., \& Járen, C. (2013). Mechanical properties of rough and dehulled rice during drying. International Journal of Food Studies, 2(2), 158-166. https://doi.org/ 10.7455/ijfs/2.2.2013.a3

Resende, O., Corrêa, P. C., Ribeiro, D. M., \& Neto Figueiredo, A. (2007). Comportamento mecânico dos grãos de feijão submetidos a compressão. Revista Brasileira de Engenharia Agrícola e Ambiental, 11(4), 404-409. https://doi.org/10.1590/S1415-43662007000400010

Ribeiro, D. M., Corrêa, P. P., Furtado, B. F., Goneli, A. L. D., \& Resende, O. (2007). Propriedades mecânicas dos grãos de soja em função do teor de água. Engenharia Agrícola, 27(2), 462-467. https://doi.org/10.1590/ S0100-69162007000300019

\section{Copyrights}

Copyright for this article is retained by the author(s), with first publication rights granted to the journal.

This is an open-access article distributed under the terms and conditions of the Creative Commons Attribution license (http://creativecommons.org/licenses/by/4.0/). 